\title{
Pengenalan karakter angka menggunakan metode Integral Proyeksi
}

\author{
Febri Liantoni \\ Teknik Informatika, Institut Teknologi Adhi Tama Surabaya, Surabaya, Indonesia \\ email:febri.liantoni@gmail.com
}

I N F O A R T I K E L

Sejarah artikel:

Menerima 7 Februari 2017

Revisi 5 Januari 2018

Diterima 5 Januari 2018

Online 5 Januari 2018

Kata kunci:

Citra digital

Integral Proyeksi

Karakter angka

Pengenalan pola

\section{Keywords:}

Digital image

Integral Projection

Numeric character

Pattern recognition

Style APA dalam mensitasi artikel ini:

Liantoni, F. (2017).

Pengenalan karakter angka

menggunakan metode

Integral Proyeksi. Register:

Jurnal Ilmiah Teknologi Sistem

Informasi, 3(2), 57-64.

\begin{abstract}
A B S T R A K
Saat ini dengan kemajuan teknologi membuat komputer memiliki kemampuan komputasi yang lebih tinggi untuk meningkatkan kemampuan dalam pengolahan data. Kemajuan teknologi ini juga berimbas pada kemampuan teknologi citra digital yang berhubungan dengan pengenalan karakter angka yang merupakan bagian dari pengenalan pola. Pengenalan karakter penting untuk pengolahan informasi yang memungkinkan proses identifikasi secara cepat dan otomatis. Pada penelitian ini dilakukan proses pengenalan karakter angka menggunakan metode Integral Proyeksi. Alasan menggunakan metode integral proyeksi karena mempunyai kelebihan pemrosesan yang sederhana dan cepat dalam mengidentifikasi suatu citra digital. Integral Proyeksi yang digunakan yaitu Integral Proyeksi vertikal dan Integral Proyeksi horisontal. Hasil penelitian menunjukkan pengenalan karakter angka mampu mengenali karakter dengan benar jika hasil praproses menghasilkan gambar yang baik. Pengenalan karakter angka akan kurang sempurna jika gambar yang diproses tidak baik, hal ini dikarenakan metode Integral Proyeksi bekerja dengan menghitung jumlah piksel tiap gambar untuk mengenai nilai gambar tersebut. Pengujian pengenalan karakater angka yang dilakukan terdapat 20 gambar uji menghasilkan nilai akurasi sebesar $65 \%$.
\end{abstract}

\section{A B S T R ACT}

Nowadays with the advancement of technology makes computers have higher computing capabilities to improve the capability of data processing. Advances in technology have also affected the ability of digital image technology related to the introduction of alphanumeric characters that are part of pattern recognition. Character recognition is important for information processing that allows rapid identification process automatically. In this research, numeric character recognition process using integral projection method. Reasons for using integral projection method for processing has the advantage of a simple and quick in identifying a digital image. The integral projection used is vertical projection and horizontal projection. The results showed numeric character recognition could recognize the characters correctly if the results of preprocessing produce good images. The introduction of the characters will be less than perfect if the images are processed is not good, this is because the integral projection method works by counting the number of pixels for each image to the value of the image. Testing the result of recognition from 20 image which is on dataset has been built to get accuracy value about $65 \%$.

๑) 2017 Register: Jurnal IImiah Teknologi Sistem Informasi. Semua hak cipta dilindungi undang-undang.

\section{Pendahuluan}

Berkembang pesatnya teknologi komunikasi berakibat juga pada penggunaan berbagai jenis model informasi. Jenis informasi yang beragam tidak hanya berbasi teks dan suara, juga mulai berkembang jenis informasi berbentuk gambar. Kemampuan pengolahan informasi dapat dilakukan dengan menggunakan komputer. Komputer merupakan alat yang dapat membantu melakukan proses-proses antara lain pengolahan citra, perhitungan, penyimpanan data dan sebagainya. Perkembangan metode pengenalan pola sangat membantu kebutuhan manusia. Salah satunya memanfaatkan teknik 
pengolahan citra dalam pengenalan suatu pola. Teknik pengolahan citra bekerja dengan cara objek gambar akan dideteksi atau memisahkan secara otomatis (klasifikasi) (Devi, Suciati, \& Khotimah, 2016)untuk melakukan tujuan tertentu sesuai keinginan pengguna.

Kemajuan teknologi membuat komputer memiliki kemampuan komputasi yang lebih tinggi untuk meningkatkan kemampuan dalam pengolahan data. Perangkat mobile juga mengalami peningkatan secara pesat terutama sistem operasi Android (Hariyanto, Wibowo, \& Noertjahyana, 2013). Dengan meningkatnya kemampuan pengolahan komputer tersebut, berakibat kerja sistem bergerak lebih cepat, sehingga bermanfaat bagi manusia, agar tidak perlu bekerja secara manual untuk memasukan data ke dalam komputer. Salah satu teknologi yang dapat digunakan untuk persoalan tersebut adalah menerapkan aplikasi pengenalan karakter dalam citra digital.

Melalui teknologi ini, membuat manusia tidak perlu mengenali karakter secara manual, hanya dengan membidik suatu citra digital, karakter dapat dikenali. Ketertarikan dengan hal itu membuat banyak penelitian yang membahas mengenai pengenalan karakter pada citra digital. Salah satu penelitian yang berkembang menjadi suatu teknologi komersial adalah Kurzweil Reading Machine pada tahun (1976) yang dibuat oleh Raymond Kurzweil, dengan mengenali tulisan cetak pada suatu citra digital (Kurzweil, 1990). Pengenalan karakter angka juga sering dilakukan untuk mengenali pelat nomor kendaraan. Pengenalan pelat nomor mobil sebagai informasi karcis parkir dilakukan oleh Setiawan, Wasista, dan Basuki (2011) dengan menggunakan metode feature reduction PCA (Principal component analysis). Amaliah, Yuniarti, Nugroho, dan Arifin (2011) melakukan penelitian dengan metode Integral Proyeksi untuk pemisahan gigi pada Dental Panoramic Radiograph. Pada penelitian ini akan dilakukan pengenalan karakter angka menggunakan Integral Proyeksi. Metode ini dilakukan dengan menghitung piksel proyeksi secara horisontal dan piksel proyeksi secara vertikal.

\section{State of the Art}

\subsection{Digital image processing}

Citra atau image merupakan sebuah angka dari segi estetika, citra atau gambar adalah kumpulan warna yang bisa terlihat indah, memiliki pola, berbentuk abstrak dan lain sebagainya. Citra dapat berupa foto udara, penampang lintang (cross section) dari suatu benda, gambar wajah, hasil tomografi otak dan lain sebagainya. Dari segi ilmiah, citra adalah gambar 3 dimensi (3D) dari suatu fungsi, biasanya intensitas warna sebagai fungsi spasial $X$ dan $Y$. Di komputer, warna dapat dinyatakan, misalnya sebagai angka dalam bentuk skala RGB (Red-Green-Blue). Karena citra adalah angka, maka citra dapat diproses secara digital (Mulyawan, Samsono, \& Setiawardhana, 2011). Suatu citra warna berisikan 3 matrik berupa matrik Red (R-layer) yang menunjukkan tingkat kecerahan untuk warna merah, matrik Green (R-layer) yang menunjukkan tingkat kecerahan untuk warna hijau, matrik Blue (B-layer) yang menunjukkan tingkat kecerahan untuk warna biru.

\subsection{Grayscale}

Grayscale (Citra keabuan) adalah berbagai nuansa warna monokromatik dari hitam menjadi putih. Oleh karena itu, gambar grayscale hanya memiliki warna abu-abu dan tidak berwarna (Indriyani, Susanto, \& Riana, 2017). Supaya citra digital bisa diolah oleh komputer, maka citra digital harus mempunyai format tertentu. Format citra digital yang dipakai adalah citra skala keabuan format citra ini disebut skala keabuan karena pada umumnya warna yang dipakai warna hitam sebagai warna minimal (0) dan warna putih (255) sebagai warna maksimalnya, sehingga warna antaranya adalah abu-abu (Indraani, Jumaddina, \& Sinaga, 2014). Informasi pallete pada citra skala keabuan ditunjukkan pada Gambar 1.

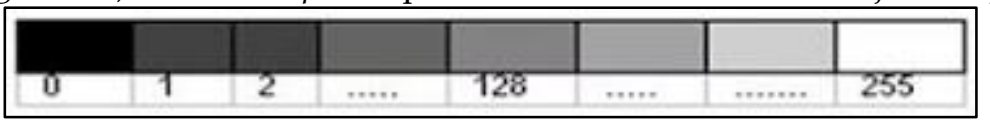

Gambar 1. Informasi pallet pada citra skala keabuan

Sebuah gambar digital dapat disimpan sebagai grayscale bentuk hitam putih, bahkan gambar berwarna berisi informasi grayscale. Hal ini karena setiap piksel memiliki nilai luminance, terlepas dari warna. Luminance juga dapat digambarkan sebagai kecerahan atau intensitas, yang dapat diukur pada skala dari hitam (nol intensitas) ke putih (intensitas penuh). Kebanyakan format file gambar 
mendukung minimal 8-bit grayscale, yang menyediakan $2^{8}$ atau level pencahayaan 256 per piksel. Beberapa format mendukung 16-bit grayscale, yang menyediakan $2^{16}$ atau level pencahayaan 65.536 (Indraani, Jumaddina, \& Sinaga, 2014).

\subsection{Thresholding}

Thresholding adalah proses konversi citra hitam-putih menjai citra biner (Hartanto, Sugiharto, \& Endah, 2014). Proses ini dikerjakan dengan cara membagi nilai derajat keabuan setiap piksel citra pada 2 kelas, yaitu hitam dan putih. Pada warna tersebut memiliki nilai skala dari 0 sampai 255 . Untuk skala tersebut, nilai intensitas 0 menyatakan warna hitam, sedangkan nilai intensitas 255 menyatakan warna putih. Untuk nilai intensitas warna keabuan dinyatakan nilai 1 sampai 254 yang terletak antara hitam dan putih.

\subsection{Binary}

Berdasarkan segmentasi citra, citra biner adalah pengubahan citra abu-abu menjadi citra biner 1 untuk putih, 0 untuk hitam dengan menggunakan operasi binerisasi (Astuti, 2010). Binerisasi dapat dilakukan ditingkat perangkat keras maupun perangkat lunak. Dalam perangkat keras binerisasi dapat ditemukan dalam kamera khusus yang sudah dirancang secara perangkat keras untuk menghasilkan citra biner, tetap sangat sedikit kegunaannya. Sedangkan untuk keperluan perangkat lunak binerisasi menggunakan nilai threshold yang didasarkan pengamatan pada citra yang disegmentasi (Astuti, 2010).

Konversi suatu citra grayscale menjadi citra biner dengan menggunakan algoritma binerisasi bekerja sebagai berikut, citra grayscale digeneralisasikan menjadi 2 bagian atau dua kelompok piksel, kemudian dua bagian tersebut dipisah oleh nilai threshold yang akan menentukan jika pada piksel dari citra berada di bawah nilai threshold, maka piksel citra tersebut akan diubah ke 0, dan jika melebihi nilai threshold maka piksel citra tersebut akan diubah ke 1 (Astuti, 2010). Binerisasi dalam hal penentuan nilai threshold diperlukan untuk mengetahui karakteristik citra yang meliputi: Sifat intensitas dari citra, ukuran citra, bagian citra yang ditempati objek, Jumlah dan jenis yang berbeda dari objek-objek yang muncul dalam citra.

\subsection{Integral Proyeksi}

Integral Proyeksi adalah suatu metode yang digunakan untuk mencari daerah atau lokasi dari objek. Metode ini dapat digunakan untuk mendeteksi batas dari daerah gambar yang berbeda, sehingga kita bisa mencari daerah lokasi, huruf, dan fitur-fiturnya. Metode ini juga bisa disebut dengan integral baris dan kolom dari piksel, karena integral ini menjumlahkan piksel per baris dan piksel per kolom (Subiyantoro \& Putra, 2011). Proses integral proyeksi seperti ditunjukkan pada Gambar 2.

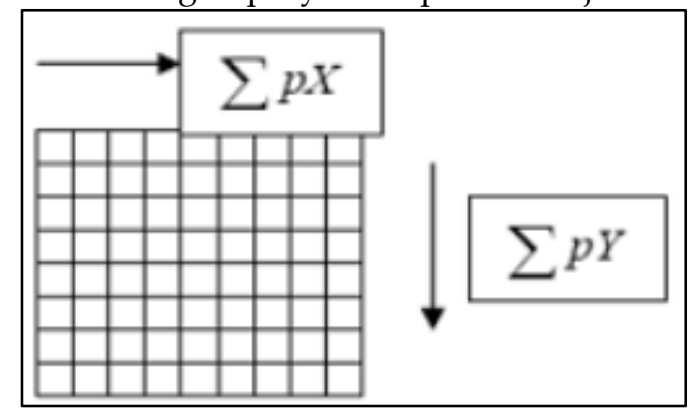

Gambar 2. Integral Proyeksi Pada Citra

Integral Proyeksi secara umum didefinisikan seperti ditunjukkan pada Persamaan 1 dan Persamaan 2 (Amaliah, Yuniarti, Nugroho, \& Arifin, 2011).

$h(i)=\sum_{i=1}^{\text {Nbaris }} x(i, j)$

$h(j)=\sum_{j=1}^{\text {Nkolom }} x(i, j)$

Di mana $h(i)$ merupakan penghitungan integral secara vertikal, sedangkan $h(j)$ merupakan penghitungan integral secara horisoltal. Contoh perhitungan bentuk Integral Proyeksi pada sebuah citra ditunjukkan pada Gambar 3. Hasil fitur integral proyeksi yang didapatkan pada contoh Gambar 3 tersebut adalah $\{0,6,2,2,6,0,4,2,2,2,2,4\}$. Dari hasil fitur yang didapatkan tersebut akan digunakan sebagai nilai identifikasi setiap gambar yang digunakan pada pengolahan citra digital.

Pengenalan karakter angka menggunakan metode Integral Proyeksi ... h https://doi.org/10.26594/register.v3il.706 (C) 2017 Register: Jurnal Ilmiah Teknologi Sistem Informasi. Semua hak cipta dilindungi undang-undang. 


\begin{tabular}{|l|l|l|l|l|l|}
\hline 0 & 1 & 1 & 1 & 1 & 0 \\
\hline 0 & 1 & 0 & 0 & 1 & 0 \\
\hline 0 & 1 & 0 & 0 & 1 & 0 \\
\hline 0 & 1 & 0 & 0 & 1 & 0 \\
\hline 0 & 1 & 0 & 0 & 1 & 0 \\
\hline 0 & 1 & 1 & 1 & 1 & 0 \\
\hline \\
\hline 0
\end{tabular}

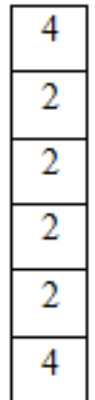

Gambar 3. Contoh bentuk integral proyeksi

\section{Metode Penelitian}

Pada penelitian ini akan dilakukan beberapa tahapan meliputi proses grayscale, binary, dan Integral Proyeksi secara vertikal dan horisontal. Gambar 4 merupakan diagram perancangan dari penelitian yang akan dilakukan.

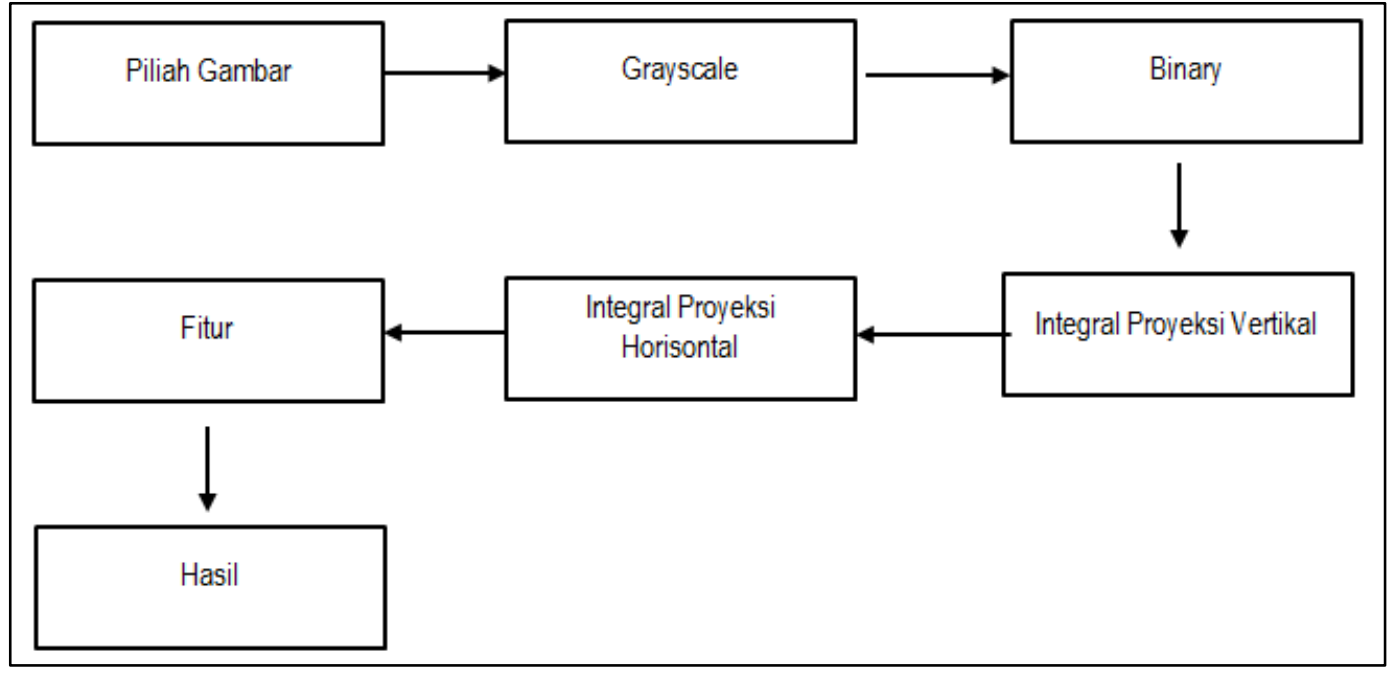

Gambar 4. Diagram metode penelitian

\subsection{Grayscale}

Data gambar dengan karakter angka sebagai masukan yang digunakan dalam sistem adalah citra RGB. Dari data citra RGB tersebut diubah menjadi citra keabuan. Perubahan citra RGB menjadi citra keabuan dengan menggunakan Persamaan 3.

gray $=\frac{(\text { red } \times 299)+(\text { green } \times 587)+(\text { blue } \times 114)}{1000}$

\subsection{Binarisasi citra}

Dari data citra RGB yang telah diubah menjadi citra grayscale yang kemudian dikonversikan menjadi citra biner dengan operasi histogram tresholding. Proses binarisasi ini akan menghasilkan gambar berwarna hitam putih. Perubahan citra menjadi citra biner dengan menggunakan Persamaan 4.

$g(x, y)=\left\{\begin{array}{l}1 \text { if } f(x, y) \geq T \\ 0 \text { if } f(x, y)<T\end{array}\right\}$

Di mana persamaan tersebut memiliki nilai dengan $g(x, y)$ adalah citra biner dari citra grayscale $f(x, y)$ dan $T$ menyatakan nilai ambang (Threshold).

\subsection{Integral Proyeksi vertikal}


Proses Integral Proyeksi vertikal digunakan untuk menghitung piksel dari gambar dengan memisahkan bagian kiri dan kanan. Proses Integral Proyeksi vertikal bekerja dengan cara menjumlahkan nilai-nilai piksel pada setiap kolom seperti yang ditunjukkan pada Persamaan 5 (Amaliah, Yuniarti, Nugroho, \& Arifin, 2011).

$\operatorname{IPV}(j)=\sum_{i=1}^{m} f(i, j)$

Di mana IPV $(j)$ merupakan penghitungan integral proyeksi vertikal, $(\mathrm{m})$ merupakan lebar citra dan $f(i, j)$ merupakan fungsi untuk menghitung jumlah integral.

\subsection{Integral Proyeksi horisontal}

Proses Integral Proyeksi horisontal digunakan untuk menghitung piksel dari gambar dengan memisahkan bagian atas dan bawah. Cara kerja metode Integral Proyeksi horisontal dengan menjumlahkan nilai piksel suatu citra secara horisontal seperti yang ditunjukkan pada Persamaan 6 (Amaliah, Yuniarti, Nugroho, \& Arifin, 2011).

$\operatorname{IPH}(i)=\sum_{j=1}^{m} f(i, j)$

Di mana $I P H(i)$ merupakan penghitungan integral proyeksi horisontal, $(\mathrm{m})$ merupakan panjang citra dan $f(i, j)$ merupakan fungsi untuk menghitung jumlah integral.

\subsection{Penentuan fitur}

Setelah dilakukan penghitungan piksel gambar dengan metode Integral Proyeksi, secara vertikal dan horisontal akan didapatkan fitur dari citra yang kemudian digunakan untuk menentukan proses pengenalan dari karakter angka. Setiap citra yang digunakan akan menghasilkan fitur yang berbedabeda. Dari nilai yang berbeda ini akan menjadi identifikasi pada proses pengenalan karakter angka yang akan dilakukan pada penelitian ini.

\section{Hasil dan Pembahasan}

Pada penelitian ini data uji dilakukan terhadap karakter angka 0 sampai 9. Uji coba pengenalan karakter angka dilakukan terhadap data uji untuk mengetahui tingkat keberhasilan metode pada aplikasi. Proses uji coba dilakukan sebanyak 20 kali untuk mengetahui akurasiyang dihasilkan. Contoh beberapan hasil uji coba pengenalan angka seperti ditunjukkan pada Gambar 5, Gambar 6 dan Gambar 7.

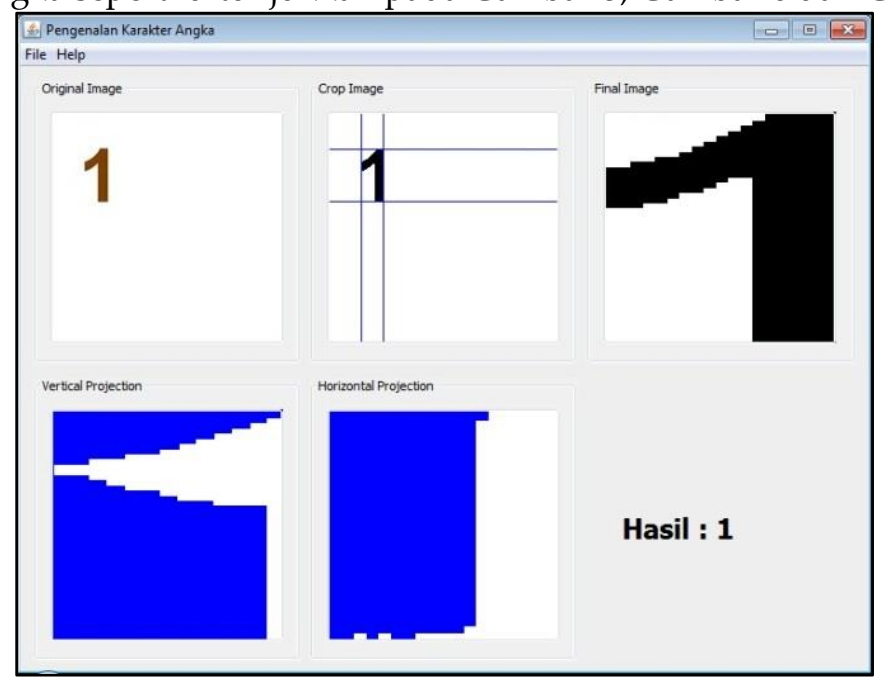

Gambar 5. Hasil Pengenalan angka 1

Pada pengenalan karakter angka dilakukan dengan proses cropping terhadap gambar uji untuk mendapatkan posisi gambar karakter yang diinginkan. Selanjutnya dilakukan penghitungan piksel menggunakan metode Integral Proyeksi baik secara vertikal maupun horisontal. Final image hasil cropping sangat berpengaruh terhadap hasil yang dihasilkan metode Integral Proyeksi karena metode ini menghitung nilai jumlah piksel dari gambar yang diolah. Seperti ditunjukkan pada Gambar 8 di mana final image yang akan diproses memiliki nilai piksel yang tidak sempurna.

Pada Gambar 8 menunjukkan hasil pengenalan karakter menghasilkan nilai yang tidak sesuai yang diinginkan yaitu menghasilkan nilai 3. Hal ini dikarenakan penghitungan piksel gambar dengan 
F. Liantoni /Register 3 (2) 57-64 integral proyeksi tidak memperoleh nilai sempurna. Maka dari itu proses cropping harus dipastikan
memperoleh gambar yang baik sehingga penghitungan piksel dengan metode Integral Proyeksi vertikal dan horisontal akan memperoleh nilai yang sempurna.

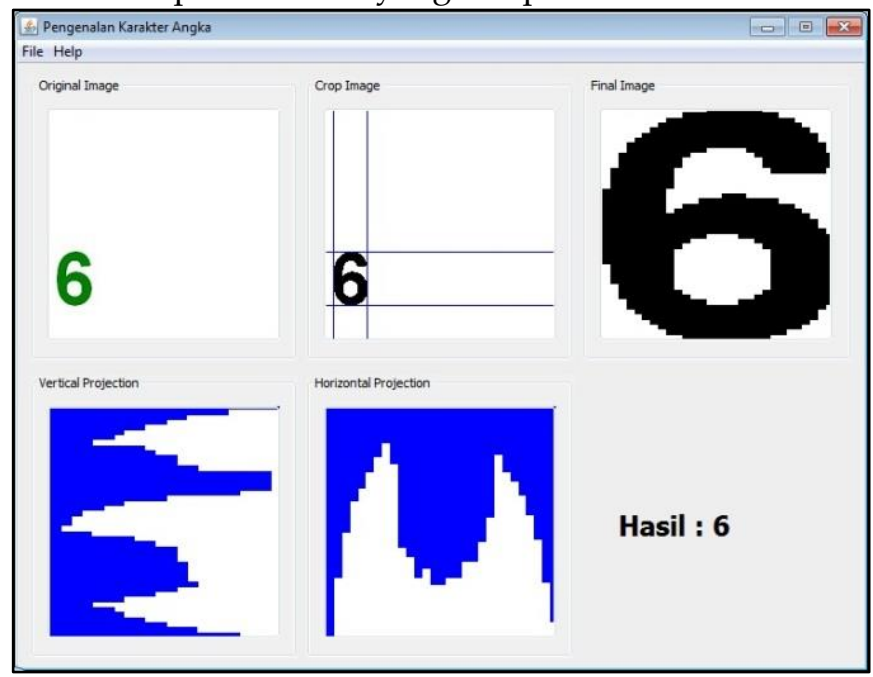

Gambar 6. Hasil Pengenalan angka 6

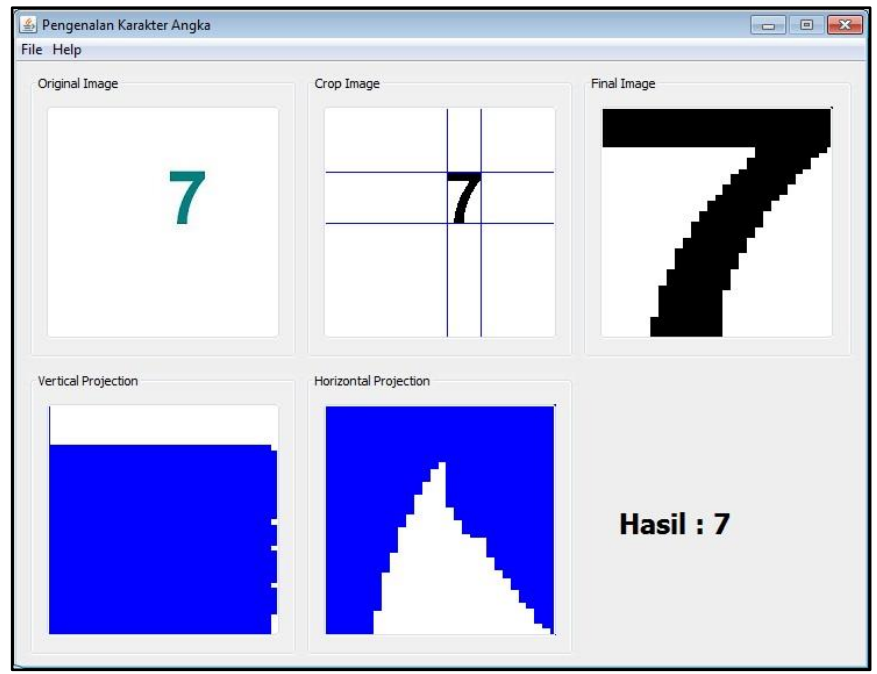

Gambar 7. Hasil Pengenalan angka 7

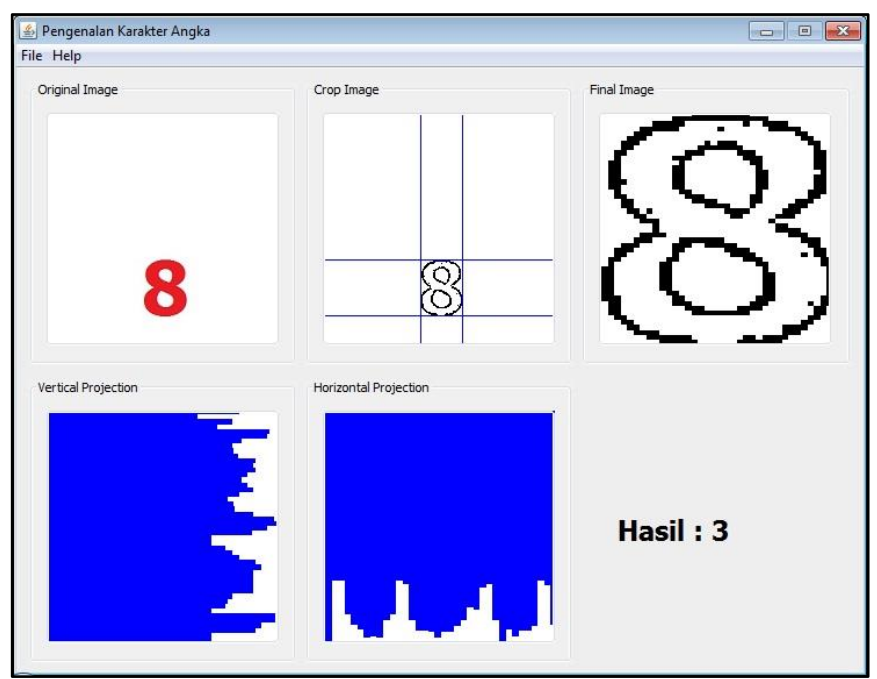

Gambar 8. Hasil uji coba pengenalan angka 8 dengan hasil salah. 
Pada Gambar 9 menunjukkan hasil pengenalan karakter yang benar karena final image memiliki nilai piksel yang baik. Berdasarkan hasil pengujian terhadap 20 gambar diperoleh 7 kali pengenalan angka yang salah atau tidak sesuai. Sedangkan sebanyak 13 gambar menghasilkan nilai yang benar atau sesuai. Dari hasil proses pengujian tersebut maka didapatkan akurasi sistem sebesar $\frac{13}{20}=65 \%$.

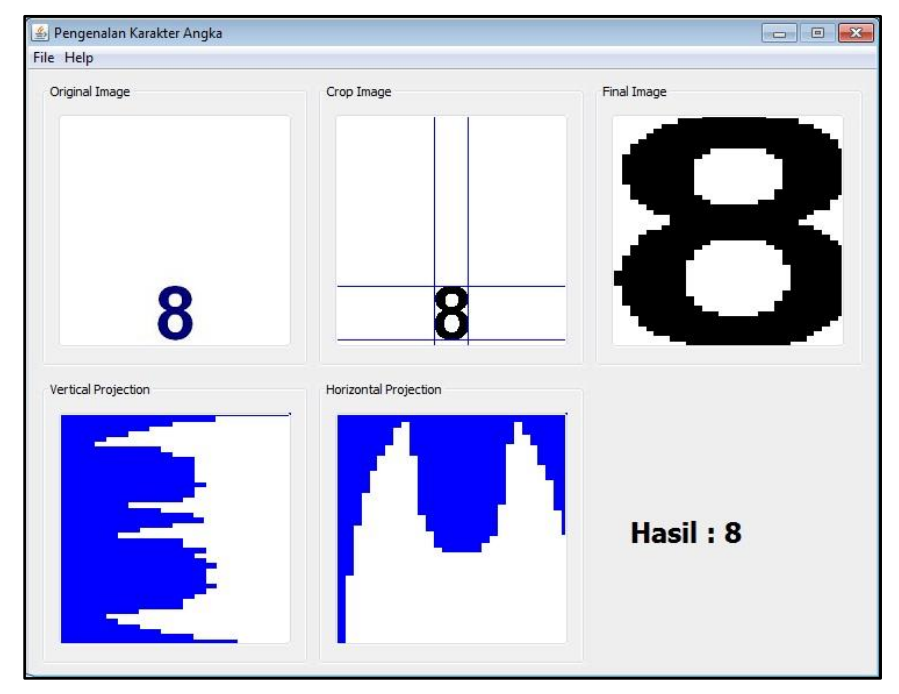

Gambar 9. Hasil uji coba pengenalan angka 8 dengan hasil benar.

\section{Kesimpulan}

Dari hasil pengujian yang telah dilakukan meliputi proses pembacaan gambar, proses grayscale, proses binary, proses cropping dan proses Integral Proyeksi didapatkan kesimpulan.

a. Metode integral proyeksi akan menghasilkan nilai yang kurang sempurna jika gambar yang diproses tidak sempurna, hal ini dikarenakan metode Integral Proyeksi bekerja dengan menghitung jumlah piksel tiap gambar untuk mengenai nilai gambar tersebut.

b. Pengujian dengan menggunakan metode Integral Proyeksi didapatkan nilai akurasi sebesar $65 \%$, hasil ini menunjukkan metode integral proyeksi mampu melakukan pengenalan karakter angka.

c. Pada penelitian selanjutnya diharapakan menerapkan metode perbaikan citra sebelum dilakukan metode Integral Proyeksi supaya menghasilkan nilai yang lebih baik.

\section{Referensi}

Amaliah, B., Yuniarti, A., Nugroho, A. S., \& Arifin, A. Z. (2011, 121-128). Pemisahan gigi pada Dental Panoramic Radiograph dengan menggunakan Integral Projection yang dimodifikasi. Jurnal Ilmiah KURSOR, 6(2).

Astuti, S. (2010). Binerisasi Otomatis Pada Citra Bergradasi Dengan Metode Variabel Dan Metode Iterasi. Techno.Com, 9(3), 53-65.

Devi, P. A., Suciati, N., \& Khotimah, W. N. (2016). Apakah kombinasi power lbp dan fourier descriptor dapat digunakan untuk klasifikasi citra kerang? TEKNOLOGI, 6(2), 68-79.

Hariyanto, A., Wibowo, A., \& Noertjahyana, A. (2013). Sistem Manajemen Skripsi Program Manajemen Bisnis Berbasis Web Service dan PhoneGap. Jurnal Infra, 1(2), 114-118.

Hartanto, S., Sugiharto, A., \& Endah, S. N. (2014). Optical character recognition menggunakan algoritma template matching correlation. Jurnal Masyarakat Informatika - J_MASIF, 5(9), 1-12.

Indraani, S. E., Jumaddina, I. D., \& Sinaga, S. R. (2014). Implementasi Edge Detection Pada Citra Grayscale dengan Metode Operator Prewitt dan Operator Sobel., (pp. 1-4).

Indriyani, L., Susanto, W., \& Riana, D. (2017). Teknik Pengolahan Citra Untuk Mengukur Diameter Buah Jeruk Keprok Menggunakan Aplikasi Matlab. Indonesian Journal on Computer and Information Technology (IJCIT), 2(1), 46-52.

Kurzweil, R. (1990). The Age of Intelligent Machines. Cambridge: MIT Press. 

processing secara real time. Surabaya: Politeknik Elektronika Negeri Surabaya.

Setiawan, A., Wasista, S., \& Basuki, D. K. (2011). Sistem pengenalan plat nomor mobil untuk aplikasi informasi karcis parkir. Surabaya: Politeknik Elektronika Negeri Surabaya.

Subiyantoro, E., \& Putra, Y. P. (2011). Penentuan kualitas daun tembakau dengan perangkat mobile berdasarkan ekstrasi fitur rata-rata rgb menggunakan algoritma k-nearest neighbor. Seminar Nasional Teknologi Informasi, Komunikai dan Aplikasinya (SNATIKA). Malang: Aptikom dan STIKI Malang. 